\title{
Adoption of Digital Marketing in Strengthening Micro, Small and Medium Enterprises in Mataram City during The Covid 19 Pandemic
}

\author{
Baiq Dewi Lita Andiana* \\ Accounting \\ Universitas Islam Al-Azhar \\ Mataram, Indonesia \\ dewilita123@gmail.com
}

\author{
Laili Hurriati \\ Economic Development \\ Universitas Islam Al-Azhar \\ Mataram, Indonesia \\ lailihurriati.86@gmail.com
}

\author{
F Fathurrahman \\ Accounting \\ Universitas Islam Al-Azhar \\ Mataram, Indonesia \\ fathurrahmanmaksi@gmail.com
}

\begin{abstract}
Micro, Small, and Medium Enterprises (MSMEs) are the backbone of national economic growth because they cover nearly $90 \%$ of business actors in Indonesia. Therefore, the government has launched various strengthening schemes for MSMEs in the form of capital strengthening programs, business management programs, and technical support. The era of the industrial revolution 4.0 with the acceleration and development of the flow of technology and information has required MSME's players to adapt to these developments in managing their business. The concept of Less Contact Economy (LCE) is a form of adaptation to order new normal life which in the current context is living side by side with the covid-19 pandemic virus. Concerning economic recovery efforts, economic actors including MSME's are required to remain active, creative, innovative, and productive even though they coexist with a deadly virus. Thus, MSMEs in running their businesses need the use of information technology during the Covid 19 pandemic. One of the most widely used digital technology platforms is digital marketing. Digital marketing is a marketing system that uses digital media to create and promote marketing messages. The purpose of this study is to describe the impact of adopting digital modeling to strengthen MSME's players in Mataram City. This study used a qualitative method, using a triangulation model. Data collection techniques used observation methods and in-depth interviews with MSME's actors who are actively registered in the Cooperative, Industry, and Trade Office Mataram. The result suggests that the adoption of digital marketing has increased during the COVID-19 pandemic. Adoption of digital marketing makes it easier for MSME players to provide information and interact directly with consumers, expand the market, increase awareness, and cost of the market of the product decreases significantly for MSME players during the Covid-19 pandemic.
\end{abstract}

Keywords-Digital Marketing, MSME's, COVID-19

\section{INTRODUCTION}

Micro, Small, and Medium Enterprises (MSMEs) are the backbone of national economic growth and have an important role in the development and growth of the Indonesian economy. The existence of the MSMEs sector assists in reducing the unemployment rate as it captive unabsorbed workforce from the formal sector. The growth of MSMEs has become a source of growth for job opportunities and income rise. Having this unique capacity made MSMEs have a strategic role in the government's efforts to overcome poverty and unemployment problems.
Apart from being one of the new employment opportunities, MSMEs also played an important role in driving the rate of economic growth after the monetary crisis when large companies experienced stagnation and even stopped their activities. MSMEs sector proved to be more resilient in dealing with this crisis. Given the experiences that Indonesia has faced during the crisis, it would not be an exaggeration if the development of the private sector is focused on MSMEs. Moreover, this business unit is often neglected merely because of the small scale in production and has not been able to compete with other larger business units. Therefore, the government and related parties need to strengthen and accelerate the development of MSMEs through several schemes/programs such as capital strengthening programs, business management programs, licensing programs, and also technical support over training and capacity building for MSMEs.

Facing the current digitalization era, almost all aspects of development are affected. It opens new opportunities and simultaneously conveys constraints. Thus, MSMEs are required to be more adaptive to technological developments in the industrial era 4.0 which offers many business opportunities which include online business transactions and online business management. This means that MSMEs need to adopt and integrate their business online. In addition, MSMEs must be able to strengthen in many ways within their own company, such as improving management skills, leadership entrepreneurs, capital management, marketing and bookkeeping skills, product development, and innovation the use of technology in running its business. The reluctance in adapting to this change lead to stagnant business or even ceased the business as they are defeated by competitors who are more adaptive to technological developments.

In the last several months, the world has suffered from the Covid-19 pandemic that affects most countries in the world including Indonesia. Countries impacted by the covid-19 outbreak have experienced a huge decline in their economic growth. Based on the OECD report (2020), the covid-19 pandemic that occurred globally has had a severe impact on the sustainability of SMEs both from the supply side and from the demand side. From the supply side, MSMEs are forced to temporarily close their businesses and reduce the number of their employees. Meanwhile, from the supply side, it is influenced by the decline in the level of consumption and public expenditure due to the Covid-19 pandemic. Some special sectors such as the tourism, arts and entertainment, and 
transportation sectors have been forced to close their businesses during the pandemic period due to policies implemented by the local government which obliges MSMEs to maintain their distance during the pandemic. This will be quite difficult to apply to the business sector [1].

In overcoming various extreme business constraints and the necessity of social distancing during the Covid-19 pandemic, the concept of LCE (The Concept of Less Contact Economy) is considered the right solution. A new form of adaptation in living a normal life (new normal) in the context of living side by side with the Covid-19 virus pandemic is a form of strategy to survive during a pandemic. This is in line with the implementation of social distancing and physical distancing regulations during the Covid-19 pandemic, where individuals are required to maintain distance from interacting with other people. The LCE concept demands the MSME's ability to be more active, creative, innovative, and more productive in finding and exploiting business opportunities accompanied by increased abilities in the use of information technology. One of the applications of the LCE concept is the use of various digital marketing platforms in conducting sales promotions for MSMEs. Digital marketing is the use of various electronic media that uses interactive technology such as email, websites, online forums and newsgroups, interactive television, mobile communication, and others which are forms of direct marketing that connect consumers and sellers (Kotler and Armstrong, 2009).

The impact of the Covid-19 pandemic faced by MSMEs in the City of Mataram is as follows: First, there is a significant decrease in sales volume during the COVID-19 outbreak. Second, the difficulties faced in market MSMEs products offline due to physical and social distancing regulations. Third, MSMEs players are forced to temporarily stop operating because the demand for their products has decreased significantly so that they choose to temporarily close their businesses rather than suffer losses. Fourth, for more than 1977 MSME actors in Mataram city, only a few have implemented and adopt digital platforms to marketing and promoting their products (low digital literacy). Therefore, this study is conducted to describe in depth how the adoption of digital marketing in strengthening MSMEs in the city of Mataram during the COVID-19 pandemic.

\section{METHODS}

This study uses a qualitative approach because the researcher intends to describe how the adoption of digital marketing is in strengthening MSMEs in the city of Mataram during the COVID-19 pandemic. Data collection method used in qualitative research is observation, interviews, and documentation. The expected data in this study can be obtained from various sources, namely MSMEs actors who are actively registered in the Cooperative, Industry, and Trade Office Mataram and one head of the sub-division of MSMEs development of Diskoperindag Kota Mataram. To perform data analysis, researchers must follow several stages subsequently data reduction, data presentation, and concluding (Moleong, 2005) The validity of the data used the triangulation technique which is used on grounds by using triangulation technique in data collection, the data obtained will be more consistent, thorough and certain (Sugiyono, 2009).

\section{RESULT AND DISCUSSION}

According to the Central Bureau of Statistics data, the number of micro, small and medium enterprises (MSMEs) in Indonesia continues to grow every year. In 2018, the number of UMKM entrepreneurs is predicted to reach 58.97 million people. This figure is predicted to continue to increase in the following years in line with technological advances and the growing potential of human resources. Likewise, the increase in the number of MSMEs in the City of Mataram is predicted to reach 25,000 MSMEs. The increase in the number of MSMEs has had a fairly good impact on the economy in the city of Mataram as it can absorb labor and unemployment. However, it turns out that there are still many MSME entrepreneurs who are constrained by business capital, marketing strategies, and access to digital technology. As a result, their business has been stagnant and has not made significant progress. To address the problems faced by MSMEs in Mataram, need the government and nongovernment agencies such as NGOs and other related parties to take part in encouraging the development of MSMEs. The strengthening scheme has been implemented through various strengthening programs such as capital assistance, implementation of training in terms of capacity building for MSMEs, technical support as well as grant in form of machines and equipment to support MSME's business operations. The current condition of MSMEs in Mataram which need continuous accompaniment and development is severed by the hit of the COVID-19 outbreak that limits people mobilization and interaction. Thus, precise strategies are required to be implemented during this harsh condition.

\section{A. Micro, Small, And Medium Enterprises (MSMEs)}

In terms of capital, there are three criteria to the cluster which business include in micro, small, or medium business. The enterprises that have asset maximum IDR 50 million with sales maximum IDR 300 million in a year are categorized as a micro-business, while business possesses more than IDR 50 to 500 million assets and with sales IDR 300 million to 2.5 billion are categorized as a small business. Enterprises with assets above IDR 500 to 10 billion and with sales above 2.5 to 50 billion are categorized as medium enterprises. Based on data collected from 35 MSMEs under fostering of Cooperative, Industry, and Trade Office Mataram that participate in this research are clustered as micro and small enterprises. The characteristics of the MSMEs involved in this research are those that are engaged in the sale of food and beverages (culinary) such as pastries and cake producers, packaged coffee producers, oyster mushroom producers, tofu producers, and electronic and motorcycle services and tent service provider. These MSMEs have small business capital of up to 25 million and have a monthly sales turnover of up to 25 million rupiahs. Meanwhile, the MSME business locations involved in this research are scattered in Mataram city. From the results of extracting information on MSMEs, it is known that the general impact experienced by MSMEs during the pandemic is a drastic drop in sales turnover. The decline in sales turnover resulted in another obstacle, namely the reduction in the amount of capital used for business. Another obstacle faced by MSMEs is the lack of knowledge of the marketing system, especially those related to the digital marketing system which is crucial to be implemented during this pandemic outbreak. This is in line with the analysis of the latest issue of Central Bureau of Statistics (BPS) NTB 
province regarding the impact of COVID-19 in the province of NTB (2020) where the biggest obstacle faced by companies due to Covid-19 in the 3rd quarter was marketing/sales of $40.74 \%$ and more than $71 \%$ of businesses need capital assistance.

\section{B. Digital Marketing}

The spread of the internet worldwide has opened abundant opportunities to boost sales and scale up business for business actors particularly MSMEs. The development of technology can be used to develop the business world. One of them is marketing communication activities that require taking advantage of the digital era in controlling market share. The concept of digital marketing is to take advantage of a wide area of media such as television, radio, mobile devices to the Internet, where the media will provide infographics about various products marketed by companies, especially the emphasis on the brand of a product or service. Digital marketing is the most powerful tool to skyrocket the brand for a product or service. Digital marketing can reach all people, anytime, in any way, and anywhere. Of course, it is very far superior to conventional marketing which is limited by time, location, and user's reach. Social distancing and restrictions hinder conventional marketing practices. Thus, open a wider prospect for digital and online marketing to be implemented. Unfortunately, more than 54\% of business actors in NTB province which include business player in Mataram city absent utilize this technology and only about $43 \%$ have used this method while $1.71 \%$ have thought of utilizing the internet and information technology since the pandemic breaks out [2]. The research result suggests that from 35 MSMEs players involved in this research, only 14 MSMEs have utilized digital marketing to promote and market their products while the other 21 MSMEs adopt conventional marketing methods. Furthermore, 14 MSMEs of 35 players have utilized social media such as Facebook, Whatsapp, and Instagram to market and promote their products. Social media is also used to remind customers about their product's excellence. Yet, unfortunately, none of them adopt digital payment in their business operation before and during a pandemic outbreak. This ease of operation in payment gate away should be attached in business transactions.

Social media is the most favored by the community. This is supported by the presence of cellular phones that provide features connected to the Internet that ease people to access social media more quickly and easily regardless of time and place. The existence of an Internet network has benefited the company to speed up marketing products while expanding the market as the internet has a wide coverage. Brand awareness as a marketing strategy is the most important factor in building consumer awareness to buy a product. This is reinforced as research results from [3] show that digital marketing in building brand awareness is carried out by managing social media Instagram by carrying out activities in the form of advertising, taglines, and running marketing mix techniques such as personal selling, sales promotion and public relations as an effort to build brand awareness about the knitted industrial products of Binong Jati.

\section{Strengthening MSMEs during the Covid-19 pandemic}

The MSMEs strengthening scheme programs that have been launched and channeled by the government and related parties such as State Minister for Cooperatives Small and Medium Enterprises (Kementerian Koperasi dan Usaha Kecil Menengah / Kemenkop UKM), Regional House of Representative West Nusa Tenggara (DPRD NTB) and Ministry of Communication and Informatics (Kementrian Momunikasi dan Informatika). The form of strengthening programs is capital assistance, workshop, and training in business management, bookkeeping, and marketing and also grant in the form of machines and equipment. In terms of digital marketing, and e-commerce literacy, and education, State Minister for Cooperatives Small and Medium Enterprises has conducted socialization about digital marketing and managing e-commerce (introduction) which involved 35 MSME players in Mataram city in 2018. This project is continued by conducting training on digital marketing and managing e-commerce for those 35 MSMEs. This was followed in 2020 by procurement of a website (NTB Mall.com) for MSMEs in NTB province that collaborated with the Ministry of Communication and Informatics (Kementrian Momunikasi dan Informatika). The other training of trainers and training for the seller (pelapak) has implemented in November 2020. This training was attended by 100 participants consist of 50 digital marketing Training Trainers who will transfer knowledge to MSMEs in all districts and cities In NTB province. Other 50 sellers are from each regency/city in Lombok Island. The training and technical assistance provided by the government have led to the adoption of digital marketing by MSMEs in Mataram city. As a result, MSMEs who adopt any digital marketing platforms such as WA, FB, Instagram, and several digital marketplace platforms (e.g. tokopedia, shopee, bukalapak) had a major impact on income. On the other hand, MSMEs who resist practicing digital marketing platforms had undergone a stagnant impact on income and business. This is following research conducted by [4], [5], [6], and [7] saying that the implementation of the Large Scale of Social Distancing (PSBB) was to break the chain of the spread of covid-19. It is feared that activities will have a deeper impact on the performance of MSMEs and the national economy. However, with the existence of a special program from the Minister of Cooperatives and SMEs, it is hoped that MSMEs actors can have a positive economic impact. Business actors can take advantage of this program and minimize the impact of the $P S B B$. In addition to implementing the program, the EMSMEs concept also brings benefits to both parties, both producers and consumers, so that online marketing carried out by MSME business people can run more effectively.

\section{Adoption of Digital Marketing in Strengthening MSMEs in Mataram City during the Covid 19 Pandemic}

MSMEs players in Mataram city who before the Covid-19 outbreak only used offline media in marketing and promoting their products tended to change their promotion system to an online marketing system during the Covid-19 pandemic. The conventional forms of marketing in promoting the products namely by using banners, brochures, business cards, and disseminating information from mouth to mouth are used before the Covid-19 pandemic and tend to shift to use digital marketing media during Covid-19. MSME players who before the pandemic had used digital marketing media such as social media, especially Facebook, Instagram, were more likely to add other digital marketing media for instance 
marketplace platforms (e.g. tokopedia, shopee, and bukalapak).

From 35 MSMEs interviewed, merely 14 business players adopt only social media marketing channels to sell their product while the other 21 implement conventional marketing methods. This indicates that MSMEs have not maximized the digital marketing system. The reason for the low number of digital marketing adoption is the illiteracy and ignorance of how to use other digital marketing platforms such as marketplace, affiliate marketing, SEO, etc. The lack of knowledge and lack of awareness of digital marketing benefits among MSMEs has led to stagnant business performance and unable to catch up with updated business development. According to Afifah et al (2018) state that "the most important factor that significantly influenced the benefits of digital marketing towards business successes (business performance) is with the knowledge that related to the use of the internet and the media contained in it" [8].

The reasons put forward by adopting the use of digital marketing in marketing and promoting products is because the marketing reach is wider to remote areas, it is also cheaper and easier to introduce and market products to potential consumers and customers because it provides space information about products and businesses. The level of awareness of potential consumers and customers of MSMEs products and businesses has increased because MSME actors can convey information and promote their products and businesses at any time and anywhere as long as an internet connection is available. Furthermore, it increased the engagement between MSME actors with potential consumers and customers because prospective consumers and customers are easier to reach and provide more frequent interactive communication occurs between sellers and potential buyers. Similar research findings suggest that the use of the internet has increased the marketing scope as well as increase consumer awareness, identify new market segments, and provide access to updated information [9]. Moreover, improving product and service quality and simultaneously utilization of technology has been adopted by 33 craft SMEs in Solo during the COVID-19 Pandemic. Improving product quality by focusing on consumer needs and crafting the innovation and creativity on the product, retaining a good relationship with supplier and distributor as well as adopting online marketing has survived craft SME's business in Solo from the Covid-19 pandemic [6].

\section{CONCLUSION}

The Covid-19 pandemic occurred at the end of 2019 and is still ongoing and has resulted in the economy sinking and impacting large businesses as well as micro, small and medium enterprises (MSMEs). The implementation of the Large Scale of Social Distancing (PSBB) and the obligation to implement health protocols resulted in difficulties for MSMEs in running their business offline, thereby drastically reducing sales levels. The use of a digital marketing media platform is a solution to increase sales of MSME products. However, the obstacle faced is that there are still many MSME players in Mataram city yet practice digital marketing media because of the low digital literacy of MSMEs. Moreover, the level of adoption is still limited to Whatsapp, Facebook, Instagram, shopee, tokopedia, and Bukalapak and only a few have business websites. On the other hand, the strengthening provided by related parties in terms of education and literacy through training on digital marketing still needs to be improved both in terms of the number of MSMEs being trained and the diversity of digital marketing materials delivered. Additionally, the government, community, and related parties need to increase awareness of the MSMEs particularly micro-businesses to adopt digital marketing to promote and market their product by providing training and workshops about digital marketing that suit their business scale. This considering the tendency of consumers to transact digitally in the future is getting higher for all level business scale. It is recommended that MSMEs in Mataram adopt not only social media marketing channel but also adopt more market place platform and other digital platforms as well as employ digital payment to smooth financial transaction and at the same time improve product and service quality and eager to innovate in term of product, consumer service, and consumer relationship.

\section{REFERENCES}

Organization for Economic Co-operation and Development (OECD), "Coronavirus (COVID-19): SME policy responses," OECD Policy Responses to Coronavirus, no. March 2020.

[2] "Dampak covid-19 di provinsi NTB BPS."

[3] F. Oktaviani and D. Rustandi, "Implementasi Digital Marketing dalam Membangun Brand Awareness," PRofesi humas J. Ilm. ilmu Hub. Masy., vol. 3, no. 1, p. 1, 2018, doi: 10.24198/prh.v3i1.15878.

[4] R. J. Anugrah, "Efektifitas penerapan strategi online marketing oleh umkm dalam masa pembatasan sosial berskala besar (psbb) corona viruses disease 2019 (covid-19)," Manova, vol. 2, no. 2, pp. $55-65,2020$.

[5] M. N. Singgih, "Strategi Penguatan Usaha Mikro Kecil Menengah (UMKM) Sebagai Refleksi Pembelajaran Krisis Ekonomi Indonesia," Ekon. Mod., vol. 3, no. 3, pp. 218-227, 2007.

[6] A. P. Nugraheni, O. L. Pramudyastuti, and S. N. Sunaningsih, "STRATEGY OF SMEs IN THE COVID-19 PANDEMIC PERIOD," J. Akunt. Perpajak. Jayakarta, vol. 2, no. 1, pp. 45-52, 2020.

[7] F. Fitriasari, "How do Small and Medium Enterprise (SME) survive the COVID-19 outbreak?," J. Inov. Ekon., vol. 5, no. 02, pp. 53-62, 2020, doi: 10.22219/jiko.v5i3.11838.

[8] A. N. Afifah, M. Najib, M. Sarma, and Y. C. Leong, "DIGITAL MARKETING ADOPTION AND THE INFLUENCES TOWARDS BUSINESS SUCCESSES OF MSMES CREATIVE SECTOR IN INDONESIA AND MALAYSIA," J. Apl. Manaj., vol. 16, no. 3, pp. 377-386, 2018, doi: 10.21776/ub.jam.2018.016.03.01.

[9] N. F. Mokhtar, "Internet Marketing Adoption by Small Business Enterprises in Malaysia," Int. J. Bus. Soc. Sci., vol. 6, no. 1, pp. $59-65,2015$. 